\title{
Effect of Using Sesbania sesban and Its Mixtures with some Summer Fresh Grasses on Lambs Productive Performance in New Reclaimed Soil
}

\author{
Zaki, M. A.**; A. A. Osman*; Fathia A. Ibrahim** and E. S. Soliman** \\ *Department of Animal Production, Faculty of Agriculture, Suez Canal University \\ ** Animal Production Research Institute, Agriculture Research Center, Egypt.
}

\section{Received: $1 / 7 / 2015$}

\begin{abstract}
The objective of this work was to study cultivation sesbania and its mixtures with sorghum or millet in reclaimed sandy soil, then utilization the green forages in feeding of growing lambs for 16 weeks in two stages (The $1^{\text {st }}$ cut was fed in the $1^{\text {st }}$ stage through the first 8 weeks and $2^{\text {nd }}$ cut was fed in the $2^{\text {nd }}$ stage through the last 8 weeks). Twenty four Ossimi lambs averaged $22.5 \mathrm{~kg}$ body weight were divided into four groups (6 in each) to evaluate the following rations: Ration A (control): 100\% from requirements of CP according to NRC(1985) from Concentrate Feed Mixture (CFM) + Rice straw ad lib., Ration B: $50 \%$ from requirements of CP according to NRC from CFM + Sesbania ad lib., Ration C: $50 \%$ from requirements of CP according to NRC from CFM + Sesbania-Sorghum mixture (1:1) ad lib. and Ration D: 50\% from requirements of CP according to NRC from CFM + Sesbania-Millet mixture (1:1) ad lib. Digestibility trials were conducted to evaluate the experimental rations using 12 rams (3 in each). The rumen parameters were measured and forage yield was determined. Results showed that $\mathrm{DM}$ and $\mathrm{CF} \%$ were lower and $\mathrm{CP} \%$ was higher in Sesbania than Sorghum, Millet, Sesbania-Sorghum mixture and Sesbania-Millet mixture. The differences among all rations in digestion coefficients of DM, OM, CP, NFE and TDN\% of tested rations were not significant. The ruminal parameters explained that the $\mathrm{pH}$ of control was significantly higher than other groups at all times in $2^{\text {nd }}$ stage, while the differences among other groups were not significant. The differences of ammonia- $\mathrm{N}$ at $2 \mathrm{hrs}$ after feeding were not significant among groups, while ammonia-N of control was significantly higher than other groups at $4 \mathrm{hrs}$, and the differences among other groups were not significant at the same time. The differences number of TVFA's among groups were not significant in $1^{\text {st }}$ stage. The differences of protozoa at $4 \mathrm{hrs}$ post feeding were not significant among all groups. The differences of microbial protein were not significant among all groups in the $1^{\text {st }}$ stage. The highest cost value of feed consumption was recorded with control. The daily body gain(DBG) were 156.1, 150.3, 154 and $154.8 \mathrm{gm} / \mathrm{h} / \mathrm{d}$ for lamb groups which fed rations A, B, C and D respectively and the differences of DBG among four groups were not significant. The best feed conversion and economical efficiency were recorded with ration $\mathrm{D}$. The green forage yield of Sesbania pure, Sesbania-Sorghum mixture and Sesbania-Millet mixture were 10.85, 15.31 and 15.30 ton/feddan, dry yield were 2.22, 3.32 and 3.34 ton/feddan, and crude protein yield were 403, 451 and 478kg/feddan, respectively.
\end{abstract}

Keywords: Sesbania, Sorghum, Millet, Rams, Lambs, Digestion coefficients, Rumen, DBG, Feed conversion, yield.

\section{INTRODUCTION}

The animals suffer from shortage of feed especially during summer season in Egypt. Most of animal feeding in this period depends on concentrate feed mixtures and agricultural residues. The expensive price of energy sources as grains or protein sources as Soybean meal and Cotton seed meal tend to increase feed cost of animals. The green forage is cheap food for ruminant feeding. The most green forages in summer season in Egypt are grasses as Sorghum, Sudan grass and Millet. Grasses have higher yield than legumes, but they are considered poor in quality due to low protein content and essential amino acids, therefore sowing legumes in mixtures with grasses improves the quality of forage by increasing protein content and reducing crude fiber content.

Some practical studies were carried out to utilization some mixtures of legumes and grasses in ruminant feeding in summer season such as cowpea with sorghum (Gabra et al., 1991), cowpea with millet (Fathia et al, 2008; Abd El-Hamid et al., 2008), Sesbania with Teosinte (Soliman et al., 1997; Soliman and Haggag, 2002), and sesbania with Sudan grass (Fathia et al., 2008; Abd El-Hamid et al., 2008). Generally, some studies were carried out for cultivation Sesbania sesban as a new legume crop in clay soils pure or its mixtures with some grasses in Egypt (Soliman et al., 1997; Haggag et al., 2000; Fathia A. Ibrahim et al., 2008; Abd El-Hamid et al., 2008).

The objective of this work is cultivation of Sesbania Sesban pure and its mixtures with sorghum or millet in reclaimed sandy soil and its utilization instead of a part from concentrate feed mixture in feeding of sheep.

\section{MATERIALS AND METHODS}

This study was carried out at Ismailia Research Station (Ismailia governorate) and Animal Nutrition Unit of Ismailia (Animal Production Research Institute), Agricultural Research Center and Research laboratories, Faculty of Agricultural, Suez Canal University, Egypt. Cultivation was practiced in reclaimed sandy soil of Ismailia Research Station farm.

The green forages were cultivated during summer season. Pure Sesbania, Sesbania-Sorghum mixture and Sesbania-Millet mixture were cultivated for feeding sheep. The normal recommended agronomic practices of forages in sandy soil as fertilization and irrigation were applied. Two cuts from green forages were taken. The $1^{\text {st }}$ cut was done after about 60 days from planting. The $2^{\text {nd }}$ cut was taken after about 45 days from the $1^{\text {st }}$ Cut. The yield of Sesbania, SesbaniaSorghum mixture and Sesbania-Millet mixture were estimated.

Four experimental rations were used as the follows: 
Ration A (control): $100 \%$ Concentrate Feed Mixture (CFM) as requirements of CP according to NRC (1985) + Rice straw ad lib.

Ration B: $50 \%$ CFM of requirements of $\mathrm{CP}$ according to $\mathrm{NRC}+$ Sesbania ad lib.

Ration C: $50 \%$ CFM of requirements of $\mathrm{CP}$ according to NRC + Sesbania-Sorghum mix. (1:1) ad lib.

Ration D: $50 \%$ CFM of requirements of CP according to NRC + Sesbania-Millet mix. (1: 1) ad lib.

Four digestibility trials were conducted to evaluate the experimental rations using 12 rams (3 in each), 2-3 years age and an average weight of $40 \mathrm{~kg}$. Rams were individually housed in metabolic cages, Preliminary period was 15 days and a collection period was 5 days, followed 3 days of ruminal studies.

Composite samples of different forages and feces were dried at $60^{\circ} \mathrm{C}$ for $24 \mathrm{hrs}$ then milling to pass through a 1 $\mathrm{mm}$ screen and stored for chemical analysis. Chemical composition of representative samples of CFM, RS, forages, refusals and feces were determined according to AOAC (1985) procedures.

Rumen fluid samples were taken using a stomach tube at 0 time (before feeding), $2 \mathrm{hr}$ and $4 \mathrm{hr}$ post feeding. These samples were filtered through three layers of surgical gauze without squeezing. Ruminal $\mathrm{pH}$ was immediately estimated by digital $\mathrm{pH}$ meter. Rumen ammonia-N was determined according to Conway (1957). Total volatile fatty acids (TVFA's) were measured by the steam distillation method as described by Warner (1964). Total number of protozoa was counted by using Fuchs Rosenthal chamber. Microbial protein was determined by sodium tungestate method according to Shultz and Shultz (1970).

Twenty four growing Ossimi lambs averaged $22.5 \mathrm{~kg}$ body weight were divided into four groups (6 in each) and were randomly assigned to evaluate the productive performance of lambs fed the four rations.

The CFM was daily offered in two equal portions at 8 am and $4 \mathrm{pm}$. The green forages were weighed and offered ad lib. Residual were collected and weighed daily. Drinking water was available all time. The growth experiments lasted 16 weeks, which included two stages as 8 weeks in $1^{\text {st }}$ cut $\left(1^{\text {st }}\right.$ stage $)$ and 8 weeks in $2^{\text {nd }}$ cut $\left(2^{\text {nd }}\right.$ stage).The experimental lambs were weighed every two weeks. Feed conversion and economical efficiency were calculated.

All data were subjected to analysis was performed using the General linear Models procedure of the SAS (2002). Mean differences were compared using Duncan ' multiple range test (Duncan, 1955). Data were analyzed using the following mathematical model:

$$
\begin{aligned}
& \mathrm{Yij}=\mu+\mathrm{Ti}+\mathrm{eij} \\
& \mathrm{Yij}=\text { Individual observation. } \\
& \mu=\text { the overall mean for the trial under consideration. } \\
& \mathrm{Ti}=\text { the effect of the } \mathrm{i}^{\text {th }} \text { treatment. } \\
& \text { eij=Random residual error. }
\end{aligned}
$$

\section{RESULTS AND DISCUSSION}

Chemical Composition: The chemical composition of successive cuts of green forages and concentrate feed mixture $(\mathrm{CFM})+$ rice straw $(\mathrm{RS})$ is presented in Table (1). The DM, and CF\% were lower in Sesbania than
Sorghum, Millet, Sesbania-Sorghum mixture and Sesbania-Millet mixture in $1^{\text {st }}$ and $2^{\text {nd }}$ cuts. The CP content in Sesbania was nearly double CP in Sorghum. While CP content in Sesbania was slightly higher than its mixtures. EE content was higher in Sesbania than Sorghum and millet, while mixtures of Sesbania with Sorghum were slightly higher than Sesbania pure. NFE Content of Sorghum was slightly higher than Sesbania and its mixtures. Ash content of Sesbania was lower than Millet and Millet-Sesbania mixture. Chemical Composition values of Sesbania obtained in this study within the chemical composition data obtained by Abdel-Rahman et al. (1995), Singh et al. (1980), ElNahrawy and Soliman (1998), Haggag et al. (2000) and Soliman and Haggag (2002). However the chemical composition of mixtures depends on the kind of plants and mix percentages. Similar results were reported by Manaye et al. (2009) in Napier grass + Sesbania. Fathia et al. (2008) found that DM percent of Sesbania-Sudan grass mixture were 23.31 and $25.13 \%$ in $1^{\text {st }}$ and $2^{\text {nd }}$ cuts. The CP content in this study of Sesbania mixtures with Sorghum or Millet take the same trend obtained by Fathia et al. (2008) with Sesbania-Sudan grass mixture. Chemical Composition of the tested rations (Table 1) explained that the ration contained CFM + Sesbania had high level of CP and NFE than rations contained CFM+Sesbania-Sorghum mixture or CFM+SesbaniaMillet mixture. The three tested rations had similar values in EE and ash content. Similar trend was reported by Soliman and Haggag (2002). Who found that the mixtures of Sesbania+Teosinte $(4: 6$ ratio) + CFM had CP 15.85, NFE\% 50.68 and CF 19.43\%. Generally, the calculated chemical composition differs with different in green forage intake. The CP\% was lower and NFE\% was higher in control ration than rations contained green forage.

\section{Digestibility trials:}

Feed intake: The values of DM intake (Table 2) as $\mathrm{kg} / \mathrm{h} / \mathrm{d}, \% \mathrm{LBW}$ and $\mathrm{g} / \mathrm{kg} \mathrm{w}^{0.75}$ were significantly higher in control ration than rations contains CFM and green forages. The lowest values of DM intake were showed by rams fed ration $\mathrm{B}$. The differences between rations $\mathrm{C}$ and D were not significant. The values of DM intake (\% of LBW) in this study were nearly similar with values recorded by El-Nahrawy and Soliman (1998) and Haggag et al. (2000). Soliman et al. (1997) found that average DM intake from Sesbania + CFM, Sesbania + Teosinte + CFM were $3.03,2.70 \%$ of LBW of goats.

Digestion coefficients: The differences among all rations in digestion coefficients of $\mathrm{DM}, \mathrm{OM}, \mathrm{CP}$ and NFE\% of tested rations were not significant (Table 2). The CF digestibility of rations $\mathrm{C}$ and $\mathrm{D}$ were significantly higher than ration $\mathrm{B}$ or control in the $1^{\text {st }}$ stage, while the differences among all rations in $2^{\text {nd }}$ stage were not significant. The DM and OM digestibility agreed with those obtained by Soliman and Haggag (2002). The CF and NFE digestibility were nearly similar with Rekib and Shukla (1995). On the other hand DM and OM digest ability in this study were lower than that obtained by Soliman et al. (1997), ElNahrawy and Soliman (1998) and Fathia et al. (2008). 
The CP digestibility in agreement with those obtained by Fathia et al. (2008) and Ahmed et al. (2009), while the CP digestibility was higher than that obtained by Soliman et al. (1997), El-Nahrawy and Soliman (1998) and Soliman and Haggag (2002). The CF digestibility in this study was nearly similar with results obtained by Soliman and Haggag, (2002). Generally, digestion coefficients are affected by different factors as animal species, activities of rumen microbes, feed components and associated effect.

Nutritive values: The differences of TDN among four rations were not significant; the DCP of ration $\mathrm{B}$ was significantly higher than other rations (Table2). The highest value of DCP of Sesbania ration may be due to high digestibility of CP. These results agreed with those obtained by Soliman et al. (1997) with goats fed Sesbania+CFM. However, the TDN and DCP\% of Sesbania-Millet mixture in this study was nearly similar with those obtained by Fathia et al. (2008) and Soliman and Haggag (2002). El-Nahrawy and Soliman (1998) found that TDN and DCP\% of Sesbania+CFM fed by sheep were 69.90 and $14.30 \%$, respectively. Generally TDN\% is differed with different in chemical composition and nutrient digestibility, and DCP\% depends on crude protein in the rations and digestion coefficients of CP.

Table (1): Chemical composition, \% of successive cuts of green forage, Concentrate feed mixture, rice straw and calculated rations (on DM basis).

\begin{tabular}{|c|c|c|c|c|c|c|c|}
\hline \multirow{2}{*}{ Items } & \multirow{2}{*}{ DM\% } & \multicolumn{6}{|c|}{ Chemical composition (\% on DM basis) } \\
\hline & & $\mathbf{O M}$ & $\mathbf{C P}$ & $\mathbf{E E}$ & $\mathbf{C F}$ & NFE & Ash \\
\hline \multicolumn{8}{|c|}{ Green forage, $1^{\text {st }}$ cut } \\
\hline Sesnania & 19.12 & 92.08 & 19.39 & 2.66 & 17.45 & 52.58 & 7.92 \\
\hline Sorghum & 20.66 & 92.27 & 8.16 & 2.11 & 25.73 & 56.27 & 7.73 \\
\hline Millet & 21.26 & 90.58 & 11.18 & 2.04 & 27.38 & 49.98 & 9.42 \\
\hline $\begin{array}{l}\text { Sesbania-Sorghum } \\
\text { mix. }\end{array}$ & 20.46 & 92.28 & 14.11 & 3.38 & 28.67 & 46.12 & 7.72 \\
\hline Sesbania-Millet mix & 21.02 & 90.17 & 15.87 & 2.40 & 28.05 & 43.85 & 9.83 \\
\hline \multicolumn{8}{|c|}{ Green forage, $2^{\text {nd }}$ cut } \\
\hline Sesnania & 22.21 & 91.76 & 16.65 & 2.99 & 20.55 & 51.57 & 8.24 \\
\hline Sorghum & 24.32 & 92.97 & 9.24 & 2.39 & 26.75 & 54.59 & 7.03 \\
\hline Millet & 23.56 & 89.38 & 8.09 & 2.01 & 27.41 & 51.87 & 10.62 \\
\hline $\begin{array}{l}\text { Sesbania-Sorghum } \\
\text { mix. }\end{array}$ & 23.27 & 92.04 & 12.94 & 3.51 & 28.77 & 46.82 & 7.96 \\
\hline Sesbania-Millet mix & 22.89 & 89.80 & 12.37 & 2.50 & 27.63 & 47.30 & 10.20 \\
\hline $\begin{array}{l}\text { Concentrate feed } \\
\text { mixture }\end{array}$ & 94.78 & 89.98 & 17.39 & 3.21 & 13.35 & 56.03 & 10.02 \\
\hline Rice straw & 88.87 & 87.04 & 4.57 & 1.40 & 24.86 & 56.21 & 12.96 \\
\hline \multicolumn{8}{|c|}{ Calculated rations } \\
\hline \multicolumn{8}{|c|}{$1^{\text {st }}$ stage $\left(1^{\text {st }}\right.$ cut $)$} \\
\hline Ration A (Control) & 93.14 & 89.04 & 13.31 & 2.63 & 17.01 & 56.09 & 10.96 \\
\hline Ration B & 30.4 & 90.82 & 18.19 & 2.99 & 14.99 & 54.65 & 9.18 \\
\hline Ration C & 31.35 & 91.16 & 15.71 & 3.30 & 21.18 & 50.97 & 8.84 \\
\hline Ration D & 31.95 & 90.08 & 16.58 & 2.78 & 21.16 & 49.56 & 9.92 \\
\hline \multicolumn{8}{|c|}{$2^{\text {nd }}$ stage $\left(2^{\text {nd }}\right.$ cut $)$} \\
\hline Ration A (Control) & 93.04 & 88.91 & 12.73 & 2.55 & 17.53 & 56.10 & 11.09 \\
\hline Ration B & 31.19 & 90.78 & 17.06 & 3.11 & 16.59 & 54.02 & 9.22 \\
\hline Ration C & 32.34 & 91.15 & 14.87 & 3.38 & 22.08 & 50.82 & 8.85 \\
\hline Ration D & 31.96 & 89.88 & 14.75 & 2.84 & 20.85 & 51.44 & 10.12 \\
\hline
\end{tabular}


Table (2): Intake, digestion coefficients and nutritive values\% of experimental rations fed by rams.

\begin{tabular}{|c|c|c|c|c|}
\hline Items & $\begin{array}{l}\text { Ration A } \\
\text { (control) }\end{array}$ & Ration & Ration & Ration D \\
\hline \multicolumn{5}{|c|}{ Dry matter intake, $1^{\text {st }}$ stage $\left(1^{\text {st }}\right.$ cut $)$} \\
\hline CFM $(\mathrm{Kg} / \mathrm{h} / \mathrm{d})$ & 1.07 & 0.52 & 0.51 & 0.52 \\
\hline $\mathbf{R S}(\mathrm{Kg} / \mathbf{h} / \mathbf{d})$ & 0.61 & - & - & - \\
\hline Forages $(\mathrm{Kg} / \mathrm{h} / \mathrm{d})$ & - & 0.34 & 0.53 & 0.58 \\
\hline Total $(\mathrm{Kg} / \mathrm{h} / \mathrm{d})$ & $1.68^{\mathrm{a}}$ & $0.86^{\mathrm{c}}$ & $1.04^{\mathrm{b}}$ & $1.09^{\mathrm{b}}$ \\
\hline Total DM intake,(\% LBW) & $4.04^{\mathrm{a}}$ & $2.11^{\mathrm{c}}$ & $2.64^{\mathrm{b}}$ & $2.73^{\mathrm{b}}$ \\
\hline DM intake, $\left(\mathrm{g} / \mathrm{kg} \mathrm{W}^{0.75}\right)$ & $102.53^{\mathrm{a}}$ & $53.21^{\mathrm{c}}$ & $65.80^{\mathrm{b}}$ & $68.79^{\mathrm{b}}$ \\
\hline \multicolumn{5}{|c|}{ Dry matter intake, $2^{\text {nd }}$ stage $\left(2^{\text {nd }}\right.$ cut $)$} \\
\hline CFM $(\mathrm{Kg} / \mathrm{h} / \mathrm{d})$ & 1.12 & 0.53 & 0.49 & 0.51 \\
\hline $\operatorname{RS}(\mathrm{Kg} / \mathrm{h} / \mathrm{d})$ & 0.52 & - & - & - \\
\hline Forages $(\mathrm{Kg} / \mathrm{h} / \mathrm{d})$ & - & 0.44 & 0.64 & 0.56 \\
\hline Total $(\mathrm{Kg} / \mathrm{h} / \mathrm{d})$ & $1.64^{\mathrm{a}}$ & $0.97^{\mathrm{c}}$ & $1.13^{\mathrm{b}}$ & $1.07^{\mathrm{bc}}$ \\
\hline Total DM intake, $(\% \mathrm{LBW})$ & $3.53^{\mathrm{a}}$ & $2.31^{\mathrm{c}}$ & $2.98^{\mathrm{ab}}$ & $2.73^{\mathrm{bc}}$ \\
\hline DM intake, $\left(\mathrm{kg} / \mathrm{kg} \mathrm{W} \mathrm{W}^{0.75}\right)$ & $92.10^{\mathrm{a}}$ & $58.69^{c}$ & $73.70^{\mathrm{b}}$ & $68.33^{\mathrm{b}}$ \\
\hline \multicolumn{5}{|c|}{ Digestion coefficients $\%, 1^{\text {st }}$ stage $\left(1^{\text {st }}\right.$ cut $)$} \\
\hline DM & $58.32^{\mathrm{a}}$ & $59.34^{\mathrm{a}}$ & $58.62^{\mathrm{a}}$ & $62.68^{\mathrm{a}}$ \\
\hline OM & $64.86^{\mathrm{a}}$ & $66.82^{\mathrm{a}}$ & $64.23^{\mathrm{a}}$ & $69.96^{\mathrm{a}}$ \\
\hline $\mathbf{C P}$ & $72.27^{\mathrm{a}}$ & $80.35^{\mathrm{a}}$ & $75.68^{\mathrm{a}}$ & $78.02^{\mathrm{a}}$ \\
\hline CF & $46.87^{\mathrm{ab}}$ & $30.10^{\mathrm{b}}$ & $51.91^{\mathrm{a}}$ & $59.01^{\mathrm{a}}$ \\
\hline EE & $83.54^{\mathrm{a}}$ & $63.15^{\mathrm{b}}$ & $75.93^{\mathrm{ab}}$ & $74.23^{\mathrm{ab}}$ \\
\hline NFE & $67.94^{\mathrm{a}}$ & $72.60^{\mathrm{a}}$ & $64.99^{\mathrm{a}}$ & $71.70^{\mathrm{a}}$ \\
\hline \multicolumn{5}{|c|}{ Digestion coefficients $\%, 2^{\text {nd }}$ stage $\left(2^{\text {nd }}\right.$ cut $)$} \\
\hline DM & $61.14^{\mathrm{a}}$ & $60.49^{\mathrm{a}}$ & $56.81^{\mathrm{a}}$ & $64.76^{\mathrm{a}}$ \\
\hline OM & $66.89^{\mathrm{a}}$ & $67.96^{\mathrm{a}}$ & $62.42^{\mathrm{a}}$ & $69.62^{\mathrm{a}}$ \\
\hline $\mathbf{C P}$ & $77.03^{\mathrm{a}}$ & $77.61^{\mathrm{a}}$ & $73.60^{\mathrm{a}}$ & $78.06^{\mathrm{a}}$ \\
\hline CF & $50.43^{\mathrm{a}}$ & $49.54^{\mathrm{a}}$ & $51.93^{\mathrm{a}}$ & $62.82^{\mathrm{a}}$ \\
\hline $\mathbf{E E}$ & $88.60^{\mathrm{a}}$ & $81.25^{\mathrm{ab}}$ & $71.42^{\mathrm{c}}$ & $73.32^{\mathrm{bc}}$ \\
\hline NFE & $68.45^{\mathrm{a}}$ & $69.82^{\mathrm{a}}$ & $63.10^{\mathrm{a}}$ & $69.80^{\mathrm{a}}$ \\
\hline \multicolumn{5}{|c|}{ Nutritive values $\%, 1^{\text {st }}$ stage $\left(1^{\text {st }}\right.$ cut $)$} \\
\hline TDN & $60.33^{\mathrm{a}}$ & $63.05^{\mathrm{a}}$ & $61.68^{\mathrm{a}}$ & $65.60^{\mathrm{a}}$ \\
\hline DCP & $9.22^{\mathrm{c}}$ & $14.62^{\mathrm{a}}$ & $11.89^{\mathrm{b}}$ & $12.94^{\mathrm{b}}$ \\
\hline \multicolumn{5}{|c|}{ Nutritive values $\%, 2^{\text {nd }}$ stage $\left(2^{\text {nd }}\right.$ cut $)$} \\
\hline TDN & $62.47^{\mathrm{a}}$ & $64.90^{\mathrm{a}}$ & $59.91^{\mathrm{a}}$ & $65.20^{\mathrm{a}}$ \\
\hline DCP & $10.26^{\mathrm{c}}$ & $13.24^{\mathrm{a}}$ & $10.95^{\mathrm{bc}}$ & $11.51^{\mathrm{b}}$ \\
\hline
\end{tabular}

a, b and $\mathrm{c}$ means in the same row with different superscripts are significantly different $(\mathrm{P}<0.05)$.

Ruminal parameters: Ruminal parameters are presented in Table (3).

Ruminal $\mathrm{pH}$ values: The maximum $\mathrm{pH}$ values were recorded at $0 \mathrm{hr}$ (before feeding) with all groups then significantly decreased with advanced time ( 2 and $4 \mathrm{hrs})$ post feeding in all treatments. Similar trend was observed by Soliman et al. (1997), Haggag et al. (2000) and Fathia et al. (2008). The $\mathrm{pH}$ value of group fed ration $\mathrm{B}$ was significantly higher than control and insignificantly higher than other groups at $2 \mathrm{hrs}$ in $1^{\text {st }}$ 
stage, while the $\mathrm{pH}$ of group fed ration $\mathrm{C}$ was insignificantly higher than that fed ration $\mathrm{D}$ and significantly higher than other groups at $4 \mathrm{hrs}$ in the same stage. However, the $\mathrm{pH}$ of control was significantly higher than other groups at all times in $2^{\text {nd }}$ stage, while the differences among other groups were not significant. However, the obtained $\mathrm{pH}$ values after feeding ranged from 5.88 to 6.45 . These values are within the normal ranges for normally functions in rumen (5.5 to 7.3) as recorded by Hungate (1966).

Ammonia-N $\left(\mathrm{NH}_{3}-\mathrm{N}\right)$ : The $\mathrm{NH}_{3}-\mathrm{N}$ was significantly higher post feeding than before feeding. The same trend was showed by Soliman et al. (1997), Haggag et al. (2000) and Fathia et al. (2008). the differences among all groups at $2 \mathrm{hrs}$ after feeding were not significant. The $\mathrm{NH}_{3}-\mathrm{N}$ of control was significantly higher than other groups at $4 \mathrm{hrs}$, while the differences among other groups were not significant at the same time.

Nearly similar values of $\mathrm{NH}_{3}-\mathrm{N}$ of Sesbania + Tosinte + CFM were showed by Soliman et al. (1997) and with Sesbania-Sudan grass mixture + CFM which showed by Fathia et al. (2008). generally, ammonia level depends on $\mathrm{CP}$ in the rations and degradability degree of $\mathrm{CP}$ in the rumen.

Table (3): Rumen fluid parameters of rams fed on experimental rations fed by rams.

\begin{tabular}{|c|c|c|c|c|c|c|}
\hline \multirow[t]{2}{*}{ Rumen fluid parameters } & \multirow[t]{2}{*}{ Stages } & \multirow{2}{*}{$\begin{array}{l}\text { hrs.post } \\
\text { feeding }\end{array}$} & \multicolumn{4}{|c|}{ Experimental rations } \\
\hline & & & $\begin{array}{l}\text { Ration A } \\
\text { (control) }\end{array}$ & Ration B & Ration C & Ration D \\
\hline \multirow[t]{6}{*}{ pH } & stage $1^{\text {st }}$ & $\mathbf{0}$ & $7.18^{\mathrm{Aa}}$ & $7.46^{\mathrm{Aa}}$ & $7.44^{\mathrm{Aa}}$ & $7.39^{\mathrm{Aa}}$ \\
\hline & & 2 & $6.37^{\mathrm{Bb}}$ & $6.71^{\mathrm{Ba}}$ & $6.51^{\mathrm{Bab}}$ & $6.48^{\mathrm{Bab}}$ \\
\hline & & 4 & $6.28^{\mathrm{Bb}}$ & $6.38^{\mathrm{Cb}}$ & $6.68^{\mathrm{Ba}}$ & $6.51^{\mathrm{Bab}}$ \\
\hline & $2^{\text {nd }}$ stage & $\mathbf{0}$ & $7.18^{\mathrm{Aa}}$ & $6.83^{\mathrm{Ab}}$ & $6.82^{\mathrm{Ab}}$ & $6.86^{\mathrm{Aab}}$ \\
\hline & & 2 & $6.45^{\mathrm{Ba}}$ & $5.96^{\mathrm{Bb}}$ & $5.88^{\mathrm{Bb}}$ & $5.95^{\mathrm{Bb}}$ \\
\hline & & 4 & $6.30^{\mathrm{Ba}}$ & $6.07^{\mathrm{Bb}}$ & $6.11^{\mathrm{Bab}}$ & $5.99^{\mathrm{Bb}}$ \\
\hline \multirow[t]{6}{*}{$\begin{array}{l}\text { Ammonia-N } \\
\text { (mg/100 ml rumen fluid) }\end{array}$} & stage $1^{\text {st }}$ & $\mathbf{0}$ & $19.04^{\mathrm{Ba}}$ & $13.49^{\mathrm{Cb}}$ & $13.67^{\mathrm{Bb}}$ & $12.46^{\mathrm{Cb}}$ \\
\hline & & 2 & $33.37^{\mathrm{Aa}}$ & $29.07^{\mathrm{Aa}}$ & $26.37^{\mathrm{Aa}}$ & $31.87^{\mathrm{Aa}}$ \\
\hline & & 4 & $34.58^{\mathrm{Aa}}$ & $23.43^{\mathrm{Bb}}$ & $23.38^{\mathrm{Ab}}$ & $25.90^{\mathrm{Bb}}$ \\
\hline & $2^{\text {nd }}$ stage & $\overline{0}$ & $16.94^{\mathrm{Bb}}$ & $17.50^{\mathrm{Bb}}$ & $23.47^{\mathrm{Ba}}$ & $18.99^{\mathrm{C}}$ \\
\hline & & 2 & $31.26^{\mathrm{Aa}}$ & $29.87^{\mathrm{Aa}}$ & $33.18^{\mathrm{Aa}}$ & $32.15^{\mathrm{Ba}}$ \\
\hline & & 4 & $34.39^{\mathrm{Aa}}$ & $27.53^{\mathrm{Ab}}$ & $29.03^{\mathrm{Ab}}$ & $29.71^{\mathrm{Ab}}$ \\
\hline \multirow[t]{6}{*}{$\begin{array}{l}\text { T VFA's (meq/100ml rumen } \\
\text { fluid) }\end{array}$} & stage $1^{\text {st }}$ & $\mathbf{0}$ & $4.25^{\mathrm{Ba}}$ & $4.20^{\mathrm{Ba}}$ & $4.35^{\mathrm{Ba}}$ & $4.60^{\mathrm{Ba}}$ \\
\hline & & 2 & $5.92^{\mathrm{Aa}}$ & $5.90^{\mathrm{Aa}}$ & $5.63^{\mathrm{Aa}}$ & $6.40^{\mathrm{Aa}}$ \\
\hline & & 4 & $5.52^{\mathrm{Aa}}$ & $6.20^{\mathrm{Aa}}$ & $6.17^{\mathrm{Aa}}$ & $6.50^{\mathrm{Aa}}$ \\
\hline & $2^{\text {nd }}$ stage & $\mathbf{0}$ & $4.13^{\mathrm{Ba}}$ & $4.63^{\mathrm{Ba}}$ & $4.17^{\mathrm{Ba}}$ & $4.20^{\mathrm{Ba}}$ \\
\hline & & 2 & $5.73^{\mathrm{Ab}}$ & $6.70^{\mathrm{Aab}}$ & $7.00^{\mathrm{Aa}}$ & $6.33^{\mathrm{Aab}}$ \\
\hline & & 4 & $5.52^{\mathrm{Ab}}$ & $6.03^{\mathrm{Aab}}$ & $6.12^{\mathrm{Aab}}$ & $6.72^{\mathrm{Aa}}$ \\
\hline \multirow[t]{6}{*}{$\begin{array}{l}\text { Number of protozoa }\left(10^{6} / \mathrm{ml}\right. \\
\text { rumen fluid) }\end{array}$} & stage $1^{\text {st }}$ & 0 & $0.61^{\mathrm{Bbc}}$ & $0.93^{\mathrm{Aa}}$ & $0.55^{\mathrm{Bc}}$ & $0.79^{\mathrm{Bab}}$ \\
\hline & & 2 & $1.70^{\mathrm{Aa}}$ & $1.29^{\mathrm{Aab}}$ & $0.90^{\mathrm{ABb}}$ & $1.12^{\mathrm{ABb}}$ \\
\hline & & 4 & $1.91^{\mathrm{Aa}}$ & $1.66^{\mathrm{Aa}}$ & $1.29^{\mathrm{Aa}}$ & $1.43^{\mathrm{Aa}}$ \\
\hline & $2^{\text {nd }}$ stage & $\mathbf{0}$ & $0.55^{\mathrm{Bb}}$ & $0.78^{\mathrm{Ba}}$ & $0.64^{\mathrm{Bab}}$ & $0.82^{\mathrm{Ba}}$ \\
\hline & & 2 & $2.13^{\mathrm{Aa}}$ & $1.55^{\mathrm{Aa}}$ & $1.66^{\mathrm{Aa}}$ & $1.71^{\mathrm{Aa}}$ \\
\hline & & 4 & $2.22^{\mathrm{Aa}}$ & $1.53^{\mathrm{Aa}}$ & $1.72^{\mathrm{Aa}}$ & $1.55^{\mathrm{Aa}}$ \\
\hline \multirow{2}{*}{$\begin{array}{l}\text { Microbial protein }(\mathrm{g} / 100 \mathrm{ml} \\
\text { rumen fluid) }\end{array}$} & $1^{\text {st }}$ stage & 4 & $0.50^{\mathrm{a}}$ & $0.61^{\mathrm{a}}$ & $0.62^{\mathrm{a}}$ & $0.60^{\mathrm{a}}$ \\
\hline & $2^{\text {nd }}$ stage & 4 & $0.55^{\mathrm{a}}$ & $0.55^{\mathrm{a}}$ & $0.45^{b}$ & $0.50^{\mathrm{ab}}$ \\
\hline
\end{tabular}

$\overline{\mathrm{A}, \mathrm{B} \text { and } \mathrm{C}}$ means in the same column with different superscripts are significantly different $(\mathrm{P}<0.05)$.

ab and $c$ means in the same rows with different superscripts are significantly different $(\mathrm{P}<0.05)$.

The rams in $1^{\text {st }}$ stage which fed green forage were fed $1^{\text {st }}$ cut.

The rams in $2^{\text {nd }}$ stage which fed green forage were fed $2^{\text {nd }}$ cut. 
Total volatile fatty acids (TVFA's): The lowest total VFA's was recorded at $0 \mathrm{hr}$, then significantly increased at $2 \mathrm{hrs}$ and $4 \mathrm{hrs}$ post feeding, and the differences of TVFA's at $0 \mathrm{hr}$ among treatments were not significant. The differences among treatments at 2 and $4 \mathrm{hrs}$ post feeding were not significant in $1^{\text {st }}$ stage. The TVFA's of group fed ration $\mathrm{C}$ ( $2^{\text {nd }}$ stage) was significantly higher than control and insignificantly higher than other groups at $2 \mathrm{hrs}$, while group fed ration D ( $2^{\text {nd }}$ stage) was significantly higher than control and insignificantly higher than other groups at 4 hrs. The values of TVFA's in this study are lower than that obtained by Soliman et al. (1997), Haggag et al. (2000) and Fathia et al. (2008) in goats.

Total number of protozoa: The minimum number of protozoa were showed at $0 \mathrm{hr}$ with all groups then significantly increased with advanced time at 2 and 4 hrs post feeding. The total number of protozoa of control was insignificantly higher than ration $\mathrm{B}$ and significantly higher than other rations $\left(1^{\text {st }}\right.$ stage $)$ at $2 \mathrm{hrs,}$ while the differences at $4 \mathrm{hrs}$ were not significant among all rations. The differences among all rations in $2^{\text {nd }}$ stage were not significant. Generally, the number of protozoa in all rations was very high which might indicate that all rations were good balanced as reported by Hungate (1966). He reported that the number of protozoa was higher with good balanced rations than poor rations.

Microbial protein: The results indicated that similar values of microbial protein of all rations with not significant differences except the ration $\mathrm{C}\left(2^{\text {nd }}\right.$ stage $)$ was insignificantly lower than ration $\mathrm{D}$ and significantly lower than other rations. Similar results were obtained by Soliman et al. (1997) and Fathia et al. (2008) by goats.

\section{Growth performance of growing lambs:}

Feed intake of lambs: The estimated concentrate feed mixture intake of control lambs were nearly duplicated the CFM intake of other treatments according NRC (1985). The average forages intake of rations B, C and D were nearly similar (Table4). The total DM intake of control was higher than other groups, while the DM intake of other groups was nearly similar. These results in harmony with those obtained by Reedm et al. (1990), Soliman et al. (1997), Abd El-Hamid et al (2008), Ahmed et al. (2009) in Sesbania forage and Fathia et al. (2012) in Sesbania silage. The TDN intake of lambs fed control ration was relatively higher than that fed other rations, and the values of TDN intake of other rations were nearly similar. The DCP intake by lambs fed ration $\mathrm{B}$ was relatively higher than other rations, may be due to the high percent DCP of Sesbania. Fathia et al. (2012) found that TDN intake of lambs from CFM + Sesbania silage and CFM + silage of Sesbania-Millet $\mathrm{x}$ Napier hybrid was 607 and $658 \mathrm{gm} / \mathrm{h} / \mathrm{d}$.

Body weight gain: Live body weights of initial experiment of four groups were nearly equal. Final body weights of experiment in all treatments were nearly similar and the differences among four groups were not significant. Daily body gain (DBG) were 156.1, 150.3, 154 and $154.8 \mathrm{gm} / \mathrm{h} / \mathrm{d}$ for lamb groups which fed control, ration $\mathrm{B}$, ration $\mathrm{C}$ and ration $\mathrm{D}$, respectively, and the differences of DBG among four groups were not significant as shown in Table (4).

Similar values were obtained by Abd El-Hamid et al (2008) and Ahmed et al. (2009) of lambs fed CFM + Sesbania-Sudan grass mixture and was higher than Fathia et al. (2012) with lambs fed on CFM + silage containing Sesbania or Sesbania- Millet $\mathrm{x}$ Napier hybrid.

Feed conversion: The best feed conversion as $\mathrm{Kg}$ $\mathrm{DM} / \mathrm{Kg}$ gain were recorded with ration $\mathrm{D}$ and the bad feed conversion recorded with control as shown in Table4. Feed conversion in this study was nearly similar with that obtained by Soliman et al. (1997) in ration containing Sesbania + Teosinte + CFM, Abd El-Hamid et al (2008) in Sesbania-Sudan grass mixture + CFM and Fathia et al. (2012) in silage Sesbania- Millet $\mathrm{x}$ Napier hybrid + CFM and Sesbania silage + CFM.

Feed cost and economical efficiency: The highest cost value of feed consumption $(\mathrm{LE} / \mathrm{h} / \mathrm{d})$ was recorded with control and the lowest cost of feed consumption was recorded with rations $\mathrm{C}$ and $\mathrm{D}$ as shown in Table (4). The feed cost $/ \mathrm{kg}$ weight gain take the same trend of cost feed consumption. The best economical efficiency was showed in ration $\mathrm{D}$, and the bad economical efficiency was recorded with control.

Yield and cost of green forages: The obtained results in Table (5) indicated that the green forage yield $\left(1^{\text {st }}\right.$ cut $+2^{\text {nd }}$ cut) of Sesbania pure (10.85 ton/feddan) was lower than Sesbania-Sorghum mixture (15.31 ton/feddan) and Sesbania-Millet mixture (15.30 ton/feddan). The same trend was observed with dry matter yield $(2.22,3.32$ and 3.34 ton/feddan, respectively). The same trend was obtained in yield of CP, TDN and DCP. The yield obtained in this study was higher than the Sesbania yield obtained by Soliman et al. (1997), and was lower than Sesbania yield obtained by El-Nahrawy and Soliman (1998) and Haggag et al. (2000). However, the yield of green forage is affected by different factors as cultivation regions of plants, kinds, varieties, number of cuts, soil fertility and agricultural processes (as irrigation, fertilization...etc.). The total cost/ton of Sesbania was higher than Sesbania-Sorghum mixture or Sesbania-Millet mixture as shown in Table (5).

\section{CONCLUSION}

It could be concluded that the rations contained $50 \%$ CFM + Sesbania- Sorghum mixture or SesbaniaMillet mixture were better than control and group fed $50 \%$ CFM + Sesbania pure and the best ration which contained 50\% CFM + Sesbania-Millet mixture. Therefore, this mixture could cultivated in new reclaimed sandy soil in summer season then utilization in feeding of growing lambs and consequently reduce the high price of feed. 
Table (4): Intake, body gain, feed conversion and economical efficiency of lambs fed experimental rations.

\begin{tabular}{|c|c|c|c|c|}
\hline Items & Ration A (control) & Ration & Ration & Ration D \\
\hline No. of animals & 6 & 6 & 6 & 6 \\
\hline Initial weight (Kg) & $22.19^{\mathrm{a}} \pm 1.01$ & $22.50^{\mathrm{a}} \pm 1.20$ & $22.92^{\mathrm{a}} \pm 1.39$ & $22.83^{\mathrm{a}} \pm 1.13$ \\
\hline Final weight (Kg) & $39.67^{\mathrm{a}} \pm 2.04$ & $39.33^{\mathrm{a}} \pm 1.71$ & $40.17^{\mathrm{a}} \pm 1.72$ & $40.17^{\mathrm{a}} \pm 1.25$ \\
\hline \multicolumn{5}{|c|}{ Dry matter intake, $1^{\text {st }}$ stage $(0-8$ weeks $)$} \\
\hline $\operatorname{CFM}(\mathrm{Kg} / \mathrm{h} / \mathrm{d})$ & 0.907 & 0.460 & 0.461 & 0.459 \\
\hline $\mathrm{RS}(\mathrm{Kg} / \mathrm{h} / \mathbf{d})$ & 0.328 & - & - & - \\
\hline Forages $(\mathrm{Kg} / \mathrm{h} / \mathrm{d})$ & - & 0.532 & 0.584 & 0.585 \\
\hline Total $(\mathrm{Kg} / \mathrm{h} / \mathrm{d})$ & 1.234 & 0.992 & 1.045 & 1.044 \\
\hline Total DM intake,(\% LBW) & 4.73 & 3.79 & 3.92 & 3.91 \\
\hline DM intake, $\left(\mathrm{g} / \mathrm{kg} \mathrm{W}^{0.75}\right)$ & 107 & 86 & 89 & 89 \\
\hline \multicolumn{5}{|c|}{ Dry matter intake, $2^{\text {nd }}$ stage $(8-16$ weeks $)$} \\
\hline CFM $(\mathrm{Kg} / \mathrm{h} / \mathrm{d})$ & 1.162 & 0.479 & 0.480 & 0.479 \\
\hline $\mathbf{R S}(\mathrm{Kg} / \mathbf{h} / \mathbf{d})$ & 0.467 & - & - & - \\
\hline Forages $(\mathrm{Kg} / \mathbf{h} / \mathbf{d})$ & - & 0.794 & 0.813 & 0.804 \\
\hline Total $(\mathrm{Kg} / \mathrm{h} / \mathrm{d})$ & 1.629 & 1.273 & 1.293 & 1.283 \\
\hline Total DM intake, (\%LBW) & 4.79 & 3.68 & 3.67 & 3.63 \\
\hline DM intake, $\left(\mathrm{kg} / \mathrm{kg} \mathrm{W} \mathrm{W}^{0.75}\right)$ & 116 & 89 & 89 & 88 \\
\hline \multicolumn{5}{|c|}{ Feed units intakes, $1^{\text {st }}$ stage $(0-8$ weeks $)$} \\
\hline TDN intake, $\mathrm{Kg} / \mathrm{h} / \mathrm{d}$ & 0.74 & 0.63 & 0.64 & 0.68 \\
\hline DCP intake, $\mathrm{g} / \mathrm{h} / \mathrm{d}$ & 113 & 145 & 124 & 135 \\
\hline \multicolumn{5}{|c|}{ Feed units intakes, $2^{\text {nd }}$ stage $(8-16$ weeks $)$} \\
\hline TDN intake, $\mathrm{Kg} / \mathrm{h} / \mathrm{d}$ & 1.04 & 0.83 & 0.77 & 0.84 \\
\hline DCP, intake $\mathrm{g} / \mathrm{h} / \mathrm{d}$ & 171 & 169 & 142 & 148 \\
\hline \multicolumn{5}{|c|}{ Average body gain } \\
\hline Total body gain, $\mathrm{Kg} / \mathrm{h} / \mathrm{d}\left(1^{\text {st }}\right.$ stage $)$ & 7.73 & 7.33 & 7.42 & 7.75 \\
\hline Daily body gain, gm/h/d(1 ${ }^{\text {st }}$ stage $)$ & 138.0 & 130.9 & 132.5 & 138.4 \\
\hline Total body gain, $\mathrm{Kg} / \mathrm{h} / \mathrm{d}\left(2^{\text {nd }}\right.$ stage $)$ & 9.75 & 9.50 & 9.83 & 9.59 \\
\hline Daily body gain, gm/h/d(2 $2^{\text {nd }}$ stage $)$ & 174.1 & 169.6 & 175.5 & 171.3 \\
\hline Total body gain, $\mathrm{kg} / \mathrm{h} / \mathrm{d}$ & 17.48 & 16.83 & 17.25 & 17.34 \\
\hline Average daily body gain, gm/h/d & 156.1 & 150.3 & 154.0 & 154.8 \\
\hline \multicolumn{5}{|c|}{ Average feed conversion (0-16 weeks) } \\
\hline Kg DM/Kg gain & 9.3 & 7.54 & 7.63 & 7.52 \\
\hline \multicolumn{5}{|c|}{ Feed cost and economical efficiency (0-16 weeks) } \\
\hline Total feed cost $(\mathrm{LE} / \mathrm{h} / \mathrm{d})$ & 2.86 & 1.75 & 1.60 & 1.60 \\
\hline Price weight gain $L E / h / d$ ) & 5.46 & 5.26 & 5.39 & 5.42 \\
\hline Economical efficiency & 1.91 & 3.01 & 3.35 & 3.39 \\
\hline
\end{tabular}

The lambs in $1^{\text {st }}$ stage which fed green forage were fed $1^{\text {st }}$ cut.

The lambs in $2^{\text {nd }}$ stage which fed green forage were fed $2^{\text {nd }}$ cut 
Table (5): Yield and cost of Sesbania pure, Sesbania-sorghum mixture and Sesbania-Millet mixture which cultivated in reclaimed sandy soil.

\begin{tabular}{|c|c|c|c|c|c|c|c|c|c|}
\hline \multirow{2}{*}{ Items } & \multicolumn{3}{|c|}{ Sesbania pure } & \multicolumn{3}{|c|}{ Sesbania-Sorghum mix. } & \multicolumn{3}{|c|}{ Sesbania - Millet mix. } \\
\hline & $1^{\text {st }}$ cut & $2^{\text {nd }}$ cut & Total & $1^{\text {st }}$ cut & $2^{\text {nd }}$ cut & Total & $1^{\text {st }}$ cut & $2^{\text {nd }}$ cut & Total \\
\hline \multicolumn{10}{|c|}{ Yield (ton/feddan) } \\
\hline Green forage yield & 6.20 & 4.65 & 10.85 & 8.75 & 6.56 & 15.31 & 8.74 & 6.56 & 15.30 \\
\hline Dry yield & 1.19 & 1.03 & 2.22 & 1.79 & 1.53 & 3.32 & 1.84 & 1.50 & 3.34 \\
\hline CP yield & 0.231 & 0.172 & 0.403 & 0.253 & 0.198 & 0.451 & 0.292 & 0.186 & 0.478 \\
\hline TDN yield & 0.750 & 0.669 & 1.419 & 1.104 & 0.917 & 2.021 & 1.207 & 0.978 & 2.185 \\
\hline DCP yield & 0.174 & 0.136 & 0.310 & 0.213 & 0.168 & 0.381 & 0.238 & 0.173 & 0.411 \\
\hline \multicolumn{10}{|c|}{ Total cost, LE/ton } \\
\hline green forages & - & - & 160 & - & - & 114 & - & - & 114 \\
\hline Dry matter & - & - & 784 & - & - & 524 & - & - & 521 \\
\hline Crude protein & - & - & 4318 & - & - & 3858 & - & - & 3640 \\
\hline TDN & - & - & 1226 & - & - & 861 & - & - & 796 \\
\hline DCP & - & - & 5613 & - & - & 4567 & - & - & 4233 \\
\hline
\end{tabular}

Total cost/feddan were $1740 \mathrm{LE}$ in summer season included rent value, seeds and other cultivated practices

\section{REFERENCES}

Abd El-Hamid, A. A., Fathia, A. Ibrahim, M. E. Ahmed and E. S. Soliman (2008). Performance of growing lambs fed two cuts of some summer green forage mixtures of legumes and grasses. Egyptian J. sheep and goat Sci. 3(2): 53-64.

Abdel-Rahman, K. M., A. A. Kandil, S. El-Kasseheb and S. Al-Debee (1995). Chemical and nutritional studies on some forage shrubs adapted in arid region. J. Agric. Sci. Mansoura Univ., 20(8):3669.

Ahmed, M. E., A. A. Abd El-Hamid, Fathia A. Ibrahim and E. S. Soliman (2009). Nutritional and economical studies of growing lamb sand lactating goats fed different legume-grass mixtures. Egyptian, J. Nutrition and feeds, 12 (3) Special issue: 263-270.

AOAC, Association of Official Analytical Chemists (1985). Official Methods of Analysis, $14^{\text {th }}$ ED. Washington, D.C, USA.

Conway, E. J. (1957). Microdiffusion analysis and Volumetric Error Rev. Ed. Lockwood, London.

Duncan, D.B. (1955). Multiple range and multiple Ftest. Biometerics, 11: 1- 42.

El-Nahrawy, M. A. and E. S. Soliman (1998). Response of Sesbania productivity and forages quality to seeding rates and planting dates. J. Agric. Sci. Mansoura Univ., 23(1):11-17.
Fathia A. Ibrahim, M. E. Ahmed and E. S. Soliman (2008). Cultivation and evaluation of some green forage mixture and its utilization in feeding of lactating Zaraibi goats. Egyptian J. Nutrition and Feeds; 11(2): 329-341.

Fathia A. Ibrahim, E. S, Soliman, A. A. Abd El-Hamid and M. E. Ahmed (2012). Growth performance and feed utilization efficiency of rahmani lambs fed some legume and/or grass silages. Egyptian J. of sheep and goat sci. 7(2): 1-10.

Gabra, M. A., A. E. M. Khinizy and M. R. M. Moustafa (1991). Chemical and nutritional evaluation of some varieties of sorghum sown singly or intercropped with cowpea. J. Agric. Sci. Mansoura Univ. 16(12): 2807- 2816.

Haggag, M. El-H., E. S. Soliman, E. M. Gaafer and M. I. Salem (2000). Effect of phosphate fertilizer levels and seeding rates on yield, quality and nutritional evaluation of Sesbania forage by goats. J. Agric. Sci. Mansoura Univ. 25(7): 39013909.

Hungate, R. E. (1966). The rumen and its microbes. Acad. Press, NY, Lond.

Manaye, T., A. Tolera, and T. Zewdu (2009). Feed intake, digestibility and body weight gain of sheep fed Napier grass mixed with different levels of Sesbania sesban. Livestock Science 122: 24-29. 
NRC (1985). Nutrient Requirements of sheep. 6th ED; National Academy of Science, National Research Council, Washington, DC.

Reedm, J. D., H. Soller and A. Woodward (1990). Fodder tree and straw diets for sheep intake, growth, digestibility and the effects of phenolics on nitrogen utilization. Animal Feed Science and Technology, 30: 39-50.

Rekib, A. and N. P. Shukla (1995). Evaluation of Sesbania sesban as protein supplement to low grade roughage (barly bhusa) for growing calves. Indian J. Anim. Sci. 65(1): 113116-.

SAS, (2002). SAS/STAT User's Guide. Release 8.1. Statistical Analysis System. SAS Institute Inc., Cary, NC, USA.

Schultz, T. A. and E. Schultz (1970). Estimation of rumen microbial nitrogen by three analytical methods. J. Dairy Sci., 53: 781-784.
Singh, C. P. Kumar and A. Rekib (1980). Note on some aspects of the feeding value of Sesbania aegyptica fodder in goats. Indian J. of Anim. Sci. 50(11):1017-1020.

Soliman, E. S., A. E. M. Khinizy, Bahira K. Mohammed and M. El-H. Haggag (1997). Studies on using Sesbania and Teosinte forages in feeding of growing zaraibi goats. Egypt. J. Appl. Sci., 12(5): 63- 74.

Soliman, E. S., and M. El-H. Haggag (2002). Effect of feeding green forage mixtures of Sesbania and Teosinte instead of concentrate feed mixture on lactating goats. Egypt. J. Appl. Sci., 17(5): 3142.

Warner, A. C. J. (1964). Production of volatile fatty acids in the rumen. Methods of measurements. Nutr. Abstr. \& Rev. B 34: 339. 


\title{
تأثير إستخدام نبات السيسبان ومخاليطة مع بعض النجيليات على الأداء الإتتاجي للحملان في الأراضي الجديدة المستصلحة الجيات على
}

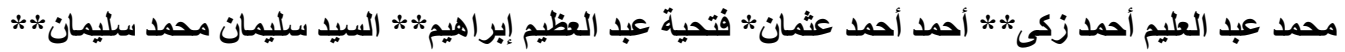

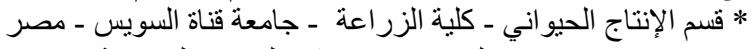

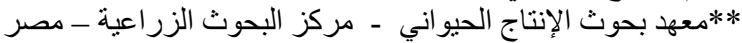

أجريت هذه الدراسة بهدف تقييم زر اعة بعض الأعلاف الصيفية الخضراء وهي السيسبان و المخاليط من السيسبان والسورجم

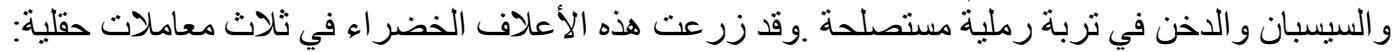

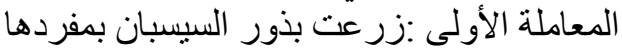

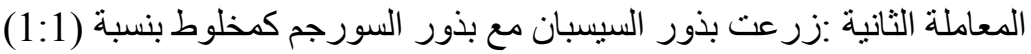

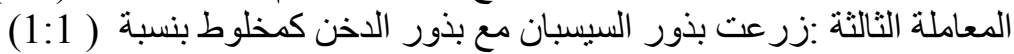

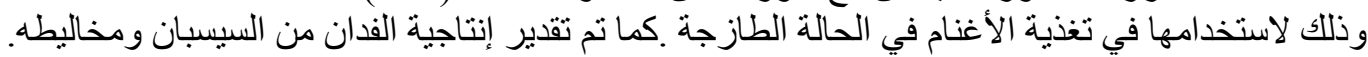

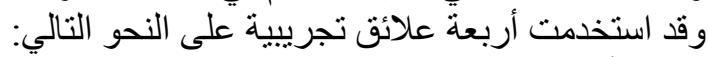

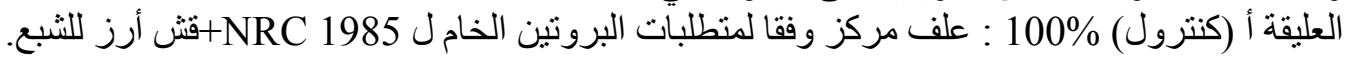

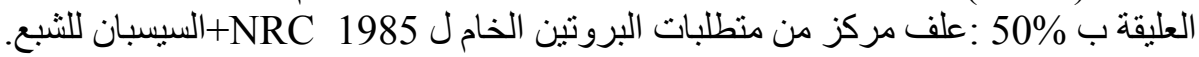

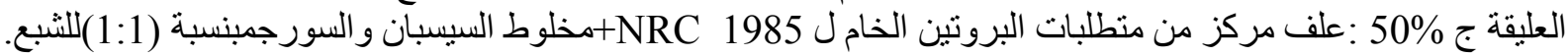

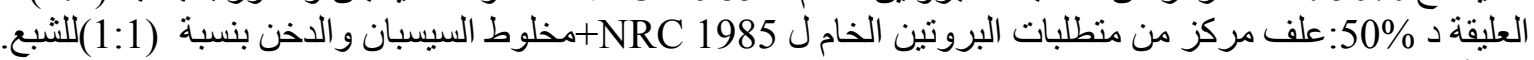

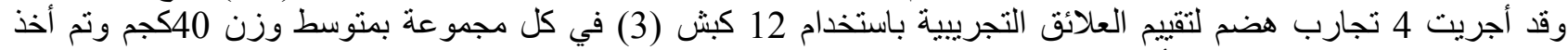

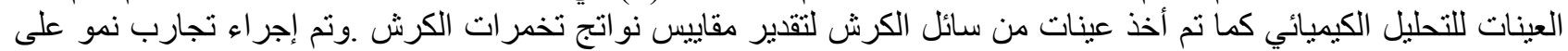

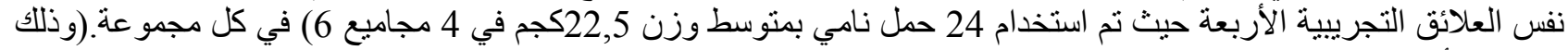

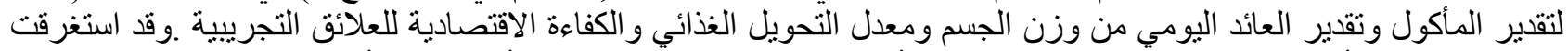

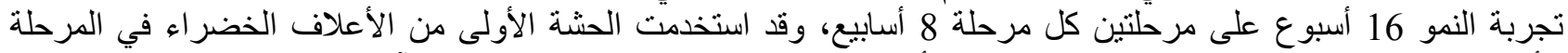

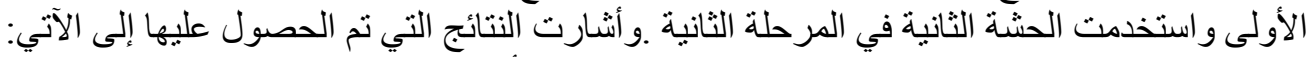
كانت نسبة المادة الجافة في السيسبان

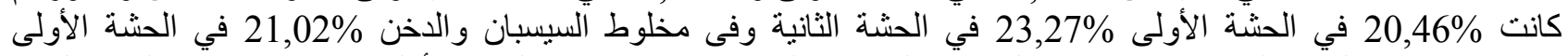

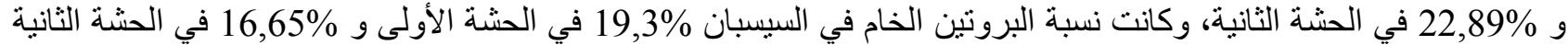
وفى مخلوط السيسبان و السورجم كانت 15,87\%

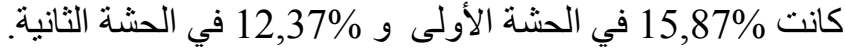

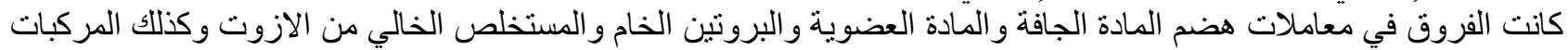

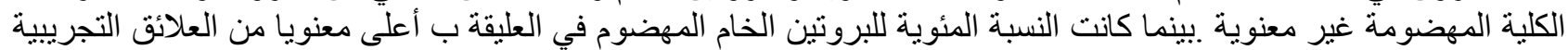

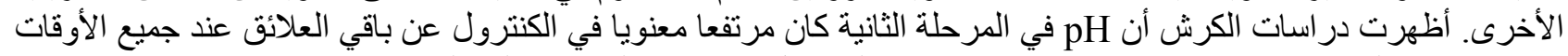

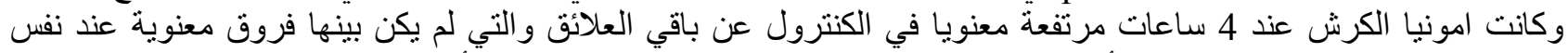

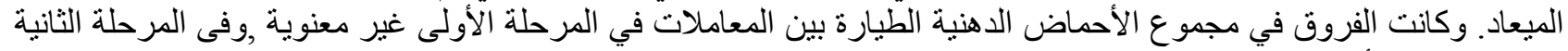

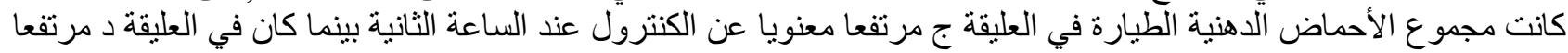

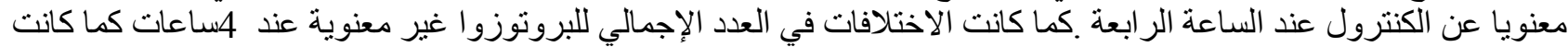

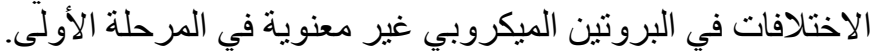
و أظهرت النتائج أن الأوز انت النهائية للمعاملات الأربعة كانت منقاربة وليس بينها اختلافات معنوية وكانية وكانت الزيادة في معدل النمو

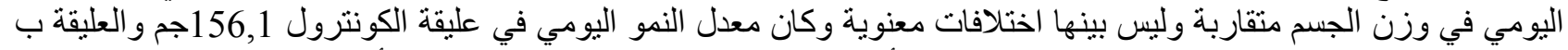

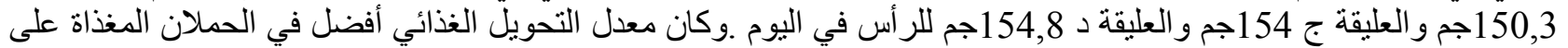

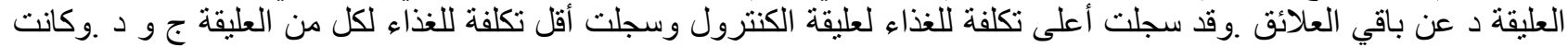

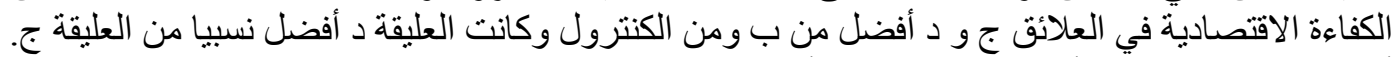

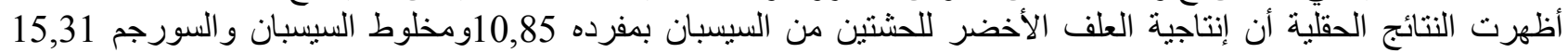

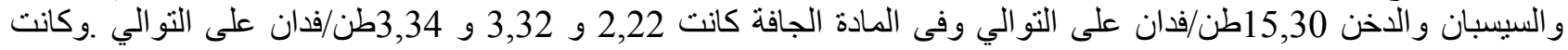

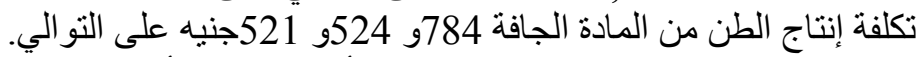
ومن النتائج التي تم الحصول عليها يمكن أن نستخلص أن العلائق التي تتكون من

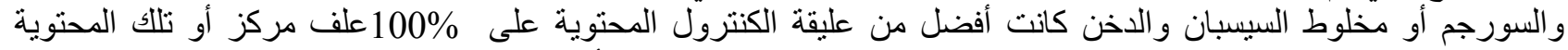

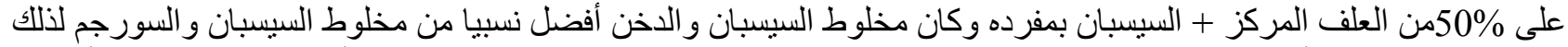

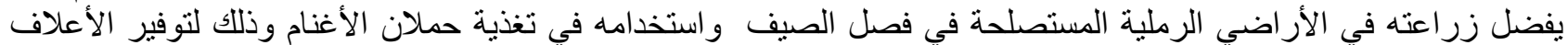

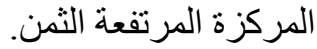

